\title{
Incidence and Antibiotic Sensitivity of Klebsiella pneumonia Isolated from Urinary Tract Infection Patients in Zakho Emergency Hospital/Iraq
}

\author{
Reem Fouad Polse ${ }^{1 *}$, Sozan Muhsin Qarani², Mahde Saleh Assafi ${ }^{3}$, Nisreen Jawad Sabaly ${ }^{4}$, \\ Fawaz F Ali ${ }^{5}$ \\ ${ }^{1}$ Department of Biology, Faculty of Science, University of Zakho, Zakho, Iraq \\ ${ }^{2}$ Department of Basic Sciences, College of Dentistry, Hawler Medical University, Erbil, Iraq \\ ${ }^{3}$ Department of Biology, School of Sciences, University of Duhok, Duhok, Iraq \\ ${ }^{4}$ Zakho Emergency Hospital, Zakho, Iraq \\ ${ }^{5}$ Department of Animal Production, Northern Technical University, Mosul, Iraq \\ E-mail: ${ }^{1 *} \underline{\text { biologyr84@yahoo.com, }}{ }^{2}$ sozan.qarani@yahoo.com, ${ }^{3}$ mahde.assafi@uod.ac,
}

(Received March 22, 2020; Accepted May 17, 2020; Available online September 01, 2020)

DOI: 10.33899/edusj.2020.126827.1056, (c) 2020, College of Education for Pure Science, University of Mosul.

This is an open access article under the CC BY 4.0 license (http://creativecommons.org/licenses/by/4.0/).

\begin{abstract}
:
Uropathogenic Klebsiella pneumoniae is considered the most important causes of urinary tract infection, and recently the antibiotic resistance of this pathogen has increased dramatically. The study aims at investigating the prevalence and antibiotic sensitivity of uropathogenic $K$. pneumoniae among different ages of groups at both genders. 1737 urine specimens were collected from individuals admitted to Zakho emergency hospital from January 2016 until December 2018. K. pneumoniae was identified based on Gram stain, colony characteristics and biochemical tests, and then it was tested for their antibiotic sensitivity. Out of all samples, $1076(61.9 \%)$ showed significant bacterial yield. The UTIs among females $(64.3 \%)$ were statistically higher than males $(46.5 \%)(P<0.001)$. The age group of 20-29 years was highly susceptible to UTIs (43\%). Among the total UTIs, K. pneumoniae represented $16.2 \%$. K. pneumoniae in males $(23.4 \%)$ was significantly higher than females $(15.4 \%)$ $(P=0.03)$. The age group $40-49$ years $(32.2 \%)$ was the highest group that at risk for $K$. pneumoniae infection. K. pneumoniae was highly susceptible to imipenem (100\%) and was highly resistant against cephalothin $(90.8 \%)$. A high prevalence of UTIs were observed among the age group of 2029 years and the females had more risk of having UTIs. The males were more susceptible to $K$. pneumoniae with higher prevalence in the age group of 40-49 years. K. pneumoniae showed high sensitivity toward imipenem and high resistance to cephalothin. More awareness is required in all healthcare sectors for regular surveillance of the use of antimicrobial agents to reduce the resistance rates and to eradicate the pathogens.
\end{abstract}

Keywords: Uropathogens, K. pneumonia, Antibiotic resistance, Zakho 


\title{
مدى الإصابة وإلحساسية للمضادات الحيوية لجرثومة الكليبيلا الرئوية المعزولة من المرضى المصابين

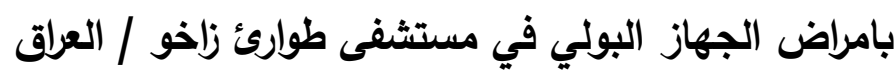

\author{
ريم فواد بولص1"، سوزان محسن قرني، مهدي صالح العسافي3، نسرين جواد سابالي، فواز فاضل علي5

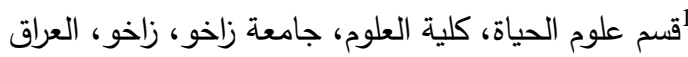

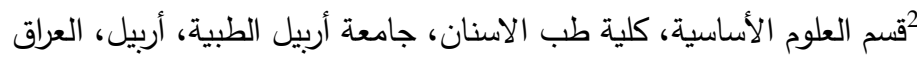

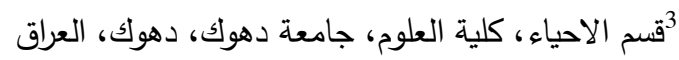 \\ 4مستشفى طوارئ زاخو، زاخو العراق \\ 5قسم الإنتاج الحيواني، الجامعة التقنية الثمالية، الموصل، العراق العرات
}

الخلاصة

يعتبر التهاب المجارى البولية بالكليبسيلا الرئوية السبب الرئيسي لعدوى المسالك البولية، وقد شهد مؤخرًا زيادة كبيرة فى مقاومتها للمضادات الحيوية. كان الهدف من الدراسة هو التحقق من مدى انتشار الكليبسيلا الرئوية المسببة لالتهاب المجاري البولية ومدى حساسيتها للدضادات الحيوية بين مختلف الفئات العمرية لدى كلا الجنسين. تم جمع 1737 عينة ادرار من الأفراد الذين تم إدخالهم لهان إلى مستشفى طوارئ زاخو من كانون الثاني 2016 حتى كانون الاول 2018. تم تثخيص الكليبسيلا الرئوية بناءً على صبغة غرام ، وخصائص المستعرة والاختبارات البيوكيميائية ثم تم اختبارها للتأكد من حساسيتها للمضادات الحيوية. من بين جميع العينات، أظهرت 1076 (61.9\%) نمو بكتيري كثيف. كانت عدوى المسالك البولية بين الإناث (64.3\%) أعلى إحصائياً من الذكور (P>0.001) (P6.5). كانت الفئة العمرية 20-29 سنة الأكثر عرضة للإصابة بعدوى المسالك البولية (43\%). (14) من بين إجمالى

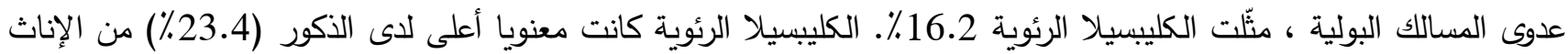

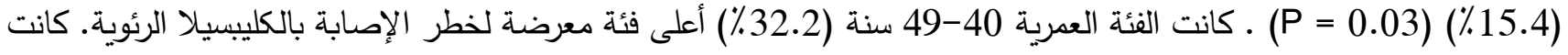
الكليبسيلا الرئوية اكثر حساسية تجاه المضاد الحيوي Imipenem (100 \%) واظهرت مقاومة عالية ضد المضاد الحيوي cephalothin عرضة لخطر عدوى المسالك البولية. كان الذكور أكثر عرضة للإصابة بالكليبسيلا الرئوية مع انتثار أعلى فى الفئة العمرية 40-

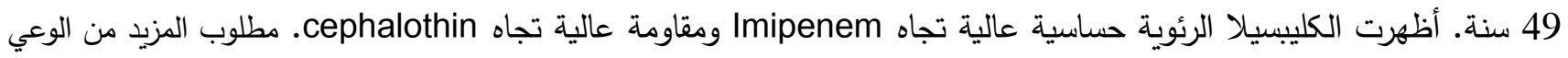
في جميع قطاعات الرعاية الصحية للمراقبة المنتظمة لاستخدام مضادات الميكروبات من أجل تقليل معدلات المقاومة والقضاء على على مسببات الأمراض.

الكلمات المفتاحية : التهاب المجاري البولية, الكليبسيلا الرئوية, مقاومة المضادات الحيوية, زاخو

\section{Introduction}

Urinary tract infections (UTIs) can be considered as the most serious and occurring types of bacterial infections in the world [1]. In spite of being treatable, UTIs are now becoming increasingly hard to control because of the extensive antimicrobial resistance among uropathogens especially those belong to Enterobacteriaceae family [2-4]. Klebsiella pneumoniae is a prominent opportunistic pathogen belong to Enterobacteriaceae family; it causes upper respiratory tract infection, diarrhea, pneumonia, urinary tract infection (UTI), and septicemia [5]. As a general rule, K. pneumoniae is 
problematic and responsible for severe infection mostly in people with a weakened immune system; the increasing spread of the strains with high virulent lead to an increasing number of individuals susceptible to infections such as healthy people [6]. Indeed, this pathogen is considered, with E. coli, as the main cause of UTIs. Though, in many reported cases, it was obvious that the pathogenicity of Klebsiella UTI was higher than E. coli [7]. K. pneumoniae pathogenicity is attributed to several virulence factors [8]. Over the past several decades, the antibiotic resistance of $K$. pneumoniae has increased due to its ability to acquire some more genetic characters to convert to more virulent or decrease its sensitivity to antibiotics [9]. Recently, the complete genomic analysis revealed that most of the strains of $K$. pneumoniae have genes, on plasmids, that are the code for antimicrobial resistance and virulence factors. This leads to a decrease in the effectiveness of these agents toward these bacteria [10]. This study conducted to isolate and investigate the antibiotic resistance of $K$. pneumoniae isolates from urine samples over a 3-year period (2016-2018) at the Zakho emergency hospital, Zakho, Kurdistan Region, Iraq.

\section{Patients and Methods}

\subsection{Specimen collection}

The cross-sectional study was performed from January 2016 until the end of December 2018 in the Zakho emergency hospital/Iraq. The urine specimens collected from 1737 patients (230 males and 1507 females) with clinical symptoms of UTI and sent to the microbiology laboratory. The patients with positive samples were detected; some information related to these patients, such as sex, age, was obtained.

\subsection{Isolation, identification, and antibiotic sensitivity test}

Urine specimens were directly inoculated aseptically on MacConkey and Brain heart infusion agar (BHI) plates and incubated for overnight at $37^{\circ} \mathrm{C}$. In the next step, the isolated bacteria were identified by Gram staining of bacterial colonies, colony character and biochemical tests, based on standard procedures and international guidelines, which were urease, catalase, oxidase, and IMViC tests (which is the abbreviation for the Indole, Methyl-red, Voges-Proskauer and Simon's Citrate test) $[11,12]$. Susceptibility to a range of antibiotics (Table 1) that were available and routinely used in hospital, was evaluated utilizing the method of disk diffusion according to the guidelines of Clinical and Laboratory Standards Institute (CLSI) 2015 [13]. 
Table 1: Antimicrobials utilized in the current study

\begin{tabular}{|l|l|}
\hline Antimicrobial group & $\begin{array}{l}\text { Antimicrobials } \\
\text { content) }\end{array}$ \\
\hline \multirow{5}{*}{ Beta-Lactams } & $\begin{array}{l}\text { Penicillins } \\
\text { Ampicillin (AM) }(10 \mu \mathrm{g}) \\
\text { Amoxicillin } \quad \text { Clavulanic acid (AMC) } \\
(20 / 10 \mu \mathrm{g}) \\
\text { Amoxicillin (AMX) }(20 \mu \mathrm{g})\end{array}$ \\
\cline { 2 - 3 } & $\begin{array}{l}\text { Cephalosporins } \\
\text { Cefixime (CFM) }(5 \mu \mathrm{g}) \\
\text { Cephalothin (KF) }(30 \mu \mathrm{g}) \\
\text { Ceftriaxone (CRO) }(30 \mu \mathrm{g}) \\
\text { Cefotaxime (CTX) }(30 \mu \mathrm{g})\end{array}$ \\
\hline \multirow{2}{*}{ Tetracycline } & $\begin{array}{l}\text { Doxycycline (DOX) }(30 \mu \mathrm{g}) \\
\text { Tetracycline (TE) }(30 \mu \mathrm{g})\end{array}$ \\
\hline Nitrofurans & Nitrofurantoin (NIT) $(300 \mu \mathrm{g})$ \\
\hline Quinolone & Nalidixic acid (NA) $(30 \mu \mathrm{g})$ \\
\hline Fluoroquinolone & $\begin{array}{l}\text { Ciprofloxacin (CIP) }(5 \mu \mathrm{g}) \\
\text { Norfloxacin (NOR) }(10 \mu \mathrm{g})\end{array}$ \\
\hline Carbapenems & $\begin{array}{l}\text { Imipenem (IMP) }(10 \mu \mathrm{g}) \\
\text { Meropenem (MEM) }(10 \mu \mathrm{g})\end{array}$ \\
\hline Macrolides & Azithromycin (AZM) $(15 \mu \mathrm{g})$ \\
\hline Aminoglycoside & $\begin{array}{l}\text { Amikacin (AK) }(30 \mu \mathrm{g}) \\
\text { Gentamicin (CN) }(10 \mu \mathrm{g})\end{array}$ \\
\hline Sulfonamides & $\begin{array}{l}\text { Trimethoprim-Sulfamethoxazole } \\
(1.25 / 23.75 \mu \mathrm{g})\end{array}$ \\
\hline Lincosamides & Clindamycin (DA) $(2 \mu \mathrm{g})$ \\
\hline
\end{tabular}

\subsection{Ethics Statement}

The patients recruited were notified and the permission for the research design and methodology was approved by the scientific committee of the department of basic sciences, Hawler Medical University/ College of Dentistry, Kurdistan, Iraq.

\subsection{Data Analysis}

SPSS 16 software was used to the statistical analysis of all data. The differences were considered significant at $P$ value $<0.05$.

\section{Results}

The study showed that between 2016-2018, a total of 1737 patients recruited. Out of all the recruited patients, only 1076 (61.9\%) samples showed significant bacterial yield. The total prevalence of UTIs among females population was $64.3 \%$ (969/1507) and in the males population, it was $46.5 \%$ $(107 / 230)$. The UTIs in females were significantly higher than males $(P<0.001)$. The highest susceptible age group of UTIs individuals irrespective of gender was found to be in the age range 2029 years (43\%) followed by age range 30-39 years (30\%), and then between 40-49 years (14\%), while the least susceptible age group of UTIs was in the 1-9 years (2\%). 
Among the total patients, the $K$. pneumoniae represented $16.17 \%$ (174/1076) of all the urinary bacteria isolated. Among the male patients through 3 years, the K. pneumoniae rate was $23.4 \%$ (25/107). While among females, the percentage of $K$. pneumoniae isolates was $15.4 \%$ (149/969) (Table 2). In the males, the UTI caused by $K$. pneumoniae was higher and statistically significant compared to the females $(P=0.03)$. During the three years of study, the highest rate of $\mathrm{K}$. pneumoniae was recorded in 2016, but the difference was statistically not significant compared to other years.

Table 2: Distribution of uropathogenic K. pneumoniae according to the gender during 2016-2018.

\begin{tabular}{|l|l|l|l|l|}
\hline Gender & $\begin{array}{l}\mathbf{2 0 1 6} \\
\mathbf{N}(\%)\end{array}$ & $\begin{array}{l}\mathbf{2 0 1 7} \\
\mathbf{N}(\%)\end{array}$ & $\begin{array}{l}\mathbf{2 0 1 8} \\
\mathbf{N}(\%)\end{array}$ & $\begin{array}{l}\text { Total } \\
\mathbf{N}(\%)\end{array}$ \\
\hline Male & $9 / 42(21.4)$ & $12 / 29(41.4)$ & $4 / 36(11.1)$ & $25 / 107(23.4)$ \\
\hline Female & $53 / 321(16.5)$ & $46 / 353(13)$ & $\begin{array}{l}50 / 295 \\
(16.9)\end{array}$ & $149 / 969(15.4)$ \\
\hline Total & $62 / 363(17.1)$ & $\begin{array}{l}58 / 382 \\
(15.2)\end{array}$ & $\begin{array}{l}54 / 331 \\
(16.3)\end{array}$ & $174 / 1076(16.2)$ \\
\hline
\end{tabular}

The highest percentage of $K$. pneumoniae isolates were from the individuals in the age range 40-49 years $(32.2 \%)$ followed by age range 30-39 years (25.9\%), and then between 20-29 years (14.9\%), while the least susceptible age group of UTIs was in the 1-9 years (2.9\%) (Table 3 ).

Table 3: Distribution of uropathogenic K. pneumoniae according to age groups during 2016-2018

\begin{tabular}{|l|l|l|l|l|}
\hline $\begin{array}{l}\text { Age group } \\
\text { (Years) }\end{array}$ & $\begin{array}{l}\mathbf{2 0 1 6} \\
\text { No }(\%)\end{array}$ & $\begin{array}{l}\mathbf{2 0 1 7} \\
\text { No }(\%)\end{array}$ & $\begin{array}{l}\mathbf{2 0 1 8} \\
\text { No }(\%)\end{array}$ & $\begin{array}{l}\text { 3 years } \\
\text { No }(\%)\end{array}$ \\
\hline $\mathbf{1 - 9}$ & $3(4.8)$ & $1(1.7)$ & $1(1.9)$ & $5(2.9)$ \\
\hline $\mathbf{1 0 - 1 9}$ & $7(11.3)$ & $11(18.9)$ & $2(3.7)$ & $20(11.5)$ \\
\hline $\mathbf{2 0 - 2 9}$ & $7(11.3)$ & $15(25.8)$ & $4(7.4)$ & $26(14.9)$ \\
\hline $\mathbf{3 0 - 3 9}$ & $18(29)$ & $14(24.1)$ & $13(24)$ & $45(25.9)$ \\
\hline $\mathbf{4 0 - 4 9}$ & $20(32.3)$ & $10(17.2)$ & $26(48.1)$ & $56(32.2)$ \\
\hline $\mathbf{5 0 - 5 9}$ & $6(9.6)$ & $3(5.2)$ & $7(13)$ & $16(9.19)$ \\
\hline$\geq \mathbf{6 0}$ & $1(1.6)$ & $4(6.9)$ & $1(1.9)$ & $6(3.4)$ \\
\hline Total & 62 & 58 & 54 & 174 \\
\hline
\end{tabular}

All the $174 \mathrm{~K}$. pneumoniae isolates in this study were screened for their antimicrobial resistance toward different classes of antibiotics. The sensitivity of $K$. pneumoniae was $100 \%$ toward imipenem $\&$ meropenem, $63.2 \%$ to nitrofurantoin, $56.9 \%$ to ciprofloxacin and $54.6 \%$ to doxycycline. While the other tested antibiotics showed less than $50 \%$. On the other hand, the $K$. pneumoniae isolates showed high resistance against cephalothin (90.8\%), ampicillin (83.3\%), cefixime (82.2\%), azithromycin (81.6\%), amoxicillin and nalidixic acid (78.2\%) (Table 4). 
Table 4: Susceptibility of the K. pneumoniae isolates against different antibiotics during 2016-2018

\begin{tabular}{|c|c|c|}
\hline \multirow{2}{*}{$\begin{array}{l}\text { Antibiotic agents } \\
\text { (Disk content) }\end{array}$} & \multicolumn{2}{|c|}{ Total isolates $(n=174)$} \\
\hline & $\begin{array}{l}\text { Resistant } \\
\text { No. }(\%)\end{array}$ & $\begin{array}{l}\text { Sensitive } \\
\text { No. }(\%)\end{array}$ \\
\hline AM $(10 \mu g)$ & $145(83.3)$ & $29(16.7)$ \\
\hline $\mathrm{AMC}(20 / 10 \mu \mathrm{g})$ & $68(39)$ & $106(61)$ \\
\hline AMX $(20 \mu g)$ & $136(78.2)$ & $38(21.8)$ \\
\hline CFM $(5 \mu \mathrm{g})$ & $143(82.2)$ & $31(17.8)$ \\
\hline KF $(30 \mu g)$ & $158(90.8)$ & $16(9.2)$ \\
\hline CRO $(30 \mu g)$ & $88(50.6)$ & $86(49.4)$ \\
\hline CTX $(30 \mu g)$ & $104(59.8)$ & $70(40.2)$ \\
\hline DOX (30 $\mu \mathrm{g})$ & $79(45.4)$ & $95(54.6)$ \\
\hline TE $(30 \mu g)$ & $88(50.6)$ & $86(49.4)$ \\
\hline NIT $(300 \mu g)$ & $64(36.8)$ & $110(63.2)$ \\
\hline NA $(30 \mu g)$ & $136(78.2)$ & $38(21.8)$ \\
\hline CIP $(5 \mu g)$ & $75(43.1)$ & $99(56.9)$ \\
\hline NOR $(10 \mu g)$ & $88(50.6)$ & $86(49.4)$ \\
\hline IMP $(10 \mu \mathrm{g})$ & $0(0)$ & $174(100)$ \\
\hline MEM (10 $\mu g)$ & $0(0)$ & $174(100)$ \\
\hline $\operatorname{AZM}(15 \mu \mathrm{g})$ & $142(81.6)$ & $32(18.4)$ \\
\hline AK $(30 \mu g)$ & $97(55.7)$ & $77(44.3)$ \\
\hline $\mathrm{CN}(10 \mu \mathrm{g})$ & $92(52.9)$ & $82(47.1)$ \\
\hline $\begin{array}{lll}\text { SXT } \\
\mu \mathrm{g})\end{array} \quad(1.25 / 23.75$ & $93(53.4)$ & $81(46.6)$ \\
\hline DA $(2 \mu \mathrm{g})$ & $101(58)$ & $73(42)$ \\
\hline
\end{tabular}

\section{Discussion}

Urinary tract infection caused by bacteria is one of the most common infections in human beings. In the current study, $61.9 \%$ of the urine specimens were positive for bacterial growth. Females showed a significant rate $(64.3 \%)$ of UTIs compared to males (46.5\%). Several studies, locally and worldwide, showed similar results $[14,15]$. Although this infection affects both genders, women are especially more prone to developing UTI compared to the men this may be due to their anatomy and reproductive physiology that allows bacterial quick access to the bladder [16]. One potential reason that could enable the auto-transmission and increasing the rate of UTIs in women could be related to the closeness of the genital tract and the urethra and anus [17]. The highest rate of UTIs was observed among people with age group 20-29 years (43\%) and 30-39 years (30\%). This might be due to the UTIs prevalence that increases with catheterization, sexual intercourse and hormonal changes such as menopause [18].

Indeed, $K$. pneumoniae comes after $E$. coli as the main cause of UTIs. Here, the $K$. pneumoniae rate among the UTIs found to be $16.2 \%$. Studies revealed varied rates for $K$. pneumoniae such as $8.8 \%$ in Italy [16], 17.1\% in Egypt [19], 23.5\% in Saudi Arabia [20]. There are different pathogens associated with UTI, but the pathogenicity of $K$. pneumoniae was the highest. $K$. pneumoniae pathogenicity is attributed to several virulence factors that give bacteria the ability to invade the host and prevent bacteria phagocytosis as well as forming a biofilm [21]. 


\section{Journal of Education and Science (ISSN 1812-125X), Vol: 29, No: 3, 2020 (257-268)}

The present study demonstrates that $K$. pneumoniae was prevalent among $23.4 \%$ of men and it was $15.4 \%$ among women. These results come in accordance to a study reported by Varughese and Beniwal [22], in India, who found that uropathogenic K. pneumoniae in males (31.6\%) was more dominant than females (7.3\%). Also, it was reported by Sattar et al., [23], in Pakistan, that men were more susceptible to uropathogenic $K$. pneumoniae. Additionally, Lee et al., [24], Korea, demonstrated that the rate of $K$. pneumoniae in UTIs was present in $7.7 \%$ of males and 5.3 in females. However, other studies revealed that female gender was more infected with uropathogenic Klebsiella spp than males [16, 25].

This study revealed that patients within the age range of 40-49 years have the highest prevalence rate with $K$. pneumoniae infection of $32.2 \%$, followed by 30-39 years (25.9\%), 20-29 years (14.9\%), while below 10 years of age showed the lowest $(2.9 \%)$. This result agrees with a study by Nirwati $e t$ $a l$., [26] and Yang and Zhang [27] who revealed that most K. pneumoniae were abundant among people in the age group of 18-65 and 40-65 years old respectively. Yang and Zhang [27] found that the age group above 70 years was with a high rate of this pathogen. It was also found that the maximum isolates were isolated from the age group of above 50 years $(85.33 \%)$ followed by age group of age 21-50 years, no K. Pneumoniae was isolated from the age group of 0-5 years shown in [28]. On the other hand, Magliano et al., [16] revealed no significant differences in isolation rates within the age groups. The age-related differences in people could be due to the response of the immune system. Adult patients (under 40 years) are likely to have stronger immune systems. Also, elderly people with an increased incidence of comorbid illness will be at higher risk of $K$. pneumoniae infection [29].

The increases of multidrug-resistant (MDR) pathogens have endangered the antibiotics treatment effectiveness [30-32]. K. pneumoniae is gaining renewed interest because of the emergence of MDR among Klebsiella associated UTI infections [33]. To guide empirical and pathogen-specific treatment for any region, it is important to know about the patterns of local antimicrobial susceptibility [34, 35]. In the present study, the pattern of antibiotic sensitivity of $K$. pneumoniae revealed that all isolates were multidrug-resistant to at least some commonly prescribed antibiotics. The $K$. pneumoniae susceptibility was $100 \%$ (174/174) to imipenem and meropenem which both belonged to carbapenem group of antibiotics making them optimal options for the empiric treatment of UTIs. Researchers found $100 \%$ susceptibility to carbapenems (imipenem and meropenem) (34). However, the overuse of these drugs will inevitably lead to selection pressure [36]. For the nitrofuran group, nitrofurantoin also found to be effective against $K$. pneumoniae isolates with the efficacy of $63.2 \%$ (110/174).

A comparable result was shown in several numbers of other studies in terms of resistance trends of Klebsiella species in urinary isolates. K. pneumoniae isolates showed varied susceptibility toward the penicillin group, for example, both ampicillin and amoxicillin showed a high resistance rate $(83.3 \%$ and $78.2 \%$ respectively) for K. pneumonia; while the combinations of amoxicillin + clavulanic acid remarkably increased the susceptibility of the isolated bacteria. Although amoxicillin alone is a broad spectrum and semisynthetic antibiotic, producing of the beta-lactamase and confirming the natural resistance to aminopenicillins by $K$. pneumoniae renders ineffective for treatment. On the other hand, clavulanic acid is effective against the clinically important plasmid-mediated $\beta$-lactamase; so the formulation of amoxicillin and clavulanic acid have the characteristic of $\beta$-lactamase inhibitor and broad-spectrum antibiotic. 


\section{Journal of Education and Science (ISSN 1812-125X), Vol: 29, No: 3, 2020 (257-268)}

The current study revealed that $K$. pneumoniae demonstrated an increased rate of resistance to first generation cephalosporins including cefixime 82.2\% (143/174) and cephalothin 90.8\% (158/174). This result was consistent with the data previously reported by [37] on UTIs. This could be explained by the most misuse of this antibiotic class and also by the fact that, with time, some strains have developed enzyme enabling them to resist to cephalosporins.

On the other hand, the susceptibility of the K. pneumoniae against third generation cephalosporin was found to be moderate with $49.4 \%(86 / 174)$ and $40.2 \%$ (70/174) for ceftriaxone and cefotaxime respectively. This result was similar to that reported by Moini and coworkers [38] who found that the resistance rate of the $K$. pneumoniae towards ampicillin and third-generation cephalosporins was 46.6\%. The resistance against penicillins and cephalosporins (including third-generation cephalosporins) found to be mediated by Extended-spectrum $\beta$-lactamases (ESBL) [39]. Studies revealed variable rates of $K$. pneumoniae isolate that produces ESBL, and they have been found that higher rates were in the Arabian region. Two separate studies conducted by Huang et al., [40] and Aljanaby and Alhasnawi [41] in Iraq showed that these proportions were $62.5 \%$ and $50 \%$, respectively.

The antimicrobial susceptibility for $K$. pneumoniae in the current study was $21.8 \%$ and $56.9 \%$ for nalidixic acid and ciprofloxacin respectively. This variation might be explained by the fact that nalidixic acid can be considered as the first generation of quinolones and the overuse of these antibiotics in UTIs confer the resistance to bacteria [42]. Subsequently, ciprofloxacin was introduced into the clinical market as the second generation of quinolones after modifications in their molecular structures to improve their antimicrobial properties and pharmacokinetic profiles [43]. Expressing of SHV genes enables bacteria to resist different antimicrobial agents including aminoglycosides. In addition to that, the three antibiotics: Gentamicin, Norfloxacin, and Trimethoprim- Sulfamethoxazole which belong to three the different groups of antibiotic showed approximately similar rates of susceptibilities.

To resist the antibiotics, several mechanisms were observed in $K$. pneumoniae [44]. In general, the $\beta$ lactamases in the bacteria hydrolyze the antibiotic $\beta$-lactam ring [45]. The resistance to some $\beta$ lactams in $K$. pneumoniae species is intrinsic because some of the resistance genes exist in the chromosome. For instance, the $S H V$ gene is regularly existed in the chromosome and conferring resistance against ampicillin $[46,47]$. Other $\beta$-lactamases could be a part of the accessory genome [48]. In addition to chromosomal resistance, $K$. pneumoniae harbor both $\beta$-lactamase and Extendedspectrum $\beta$-lactamases (ESBL)-encoding plasmids that confer resistance to most penicillin antibiotics and third-generation cephalosporins respectively [49].

The hypervirulent $K$. pneumoniae is carbapenems-susceptible [50]. However, the carbapenemresistant $K$. pneumoniae strains can convert to hypervirulent by getting a pLVPK-like virulence plasmid [51]. Carbapenem-resistant Hypervirulent $K$. pneumoniae decrease the choices of antimicrobial agents. For this reason, this considered an urgent challenge for public health [52]. Besides, carbapenem resistance in $K$. pneumoniae can also be mediated by the accessory genome. Also, carbapenem resistance in $K$. pneumoniae could be by the mutations in the chromosomal genome [53].

\section{Conclusions}


Conclusively, an overall prevalence of $61.9 \%$ UTIs was observed in the current study. Females had more risk of having UTIs than males. The UTIs in women were significantly higher than men. The UTIs were more dominant among the age group of 20-29 years patients. K. pneumoniae represented $16.2 \%$ of the isolated urinary bacteria. Males were more susceptible to uropathogenic K. pneumoniae than females. A high prevalence of $K$. pneumoniae was seen in the age group 40-49 years. The study revealed that the imipenem and meropenem as the most promising antimicrobial therapy for the treatment of UTI. K. pneumoniae isolates exhibited high resistance toward the most commonly used antibiotics. For this reason, clinicians and laboratories must be aware and more accurate testing is required to decrease the wrong therapy. Also, the current data shed light on the necessity for surveillance of microbial resistance for most of the uropathogenic bacteria to reduce the failure therapy and to enhance the methods of infection control and improve the guide of the use of antibiotics.

\section{References}

(1) Al-Naqshbandi A. A., Chawsheen M. A., and Abdulqader H. H., J. Infect. Public Health, 12(3): 330-336 (2019).

(2) Paterson D. L. and Bonomo R. A., Clin. Microbiol. Rev., 18(4): 657-86 (2005).

(3) Akreyi W. H. S., Yousif S. Y., and Assafi M. S., Jurnal Teknologi Laboratorium, 7(2): 38-45 (2018).

(4) Hussein N. R., Daniel S., Salim K., and Assafi M. S., Avicenna Journal of Clinical Microbiology and Infection, 5(2): 27-30 (2018).

(5) Mahmoudvand H., Azadpour M., Nowroozi J., and Goudarzi G., Tropical Biomedicine, 32(1): 109-115 (2015).

(6) Bengoechea J. A. and Sa Pessoa J., FEMS Microbiology Reviews, 43(2): 123-144 (2019).

(7) Farajnia S., Alikhani M. Y., Ghotaslou R., Naghili B., and Nakhlband A., Int. J. Infect. Dis., 13(2): 140-4 (2009).

(8) Struve C. and Krogfelt K. A., FEMS microbiology letters, 218(1): 149-154 (2003).

(9) Liu C. and Guo J., Annals of Clinical Microbiology and Antimicrobials, 18(1): 4 (2019).

(10) Turton J. F., Payne Z., Coward A., Hopkins K. L., Turton J. A., Doumith M., and Woodford N., Journal of Medical Microbiology, 67(1): 118-128 (2018).

(11) Carr F. J., EC Microbiology, 8(3): 123-183 (2017). 


\section{Journal of Education and Science (ISSN 1812-125X), Vol: 29, No: 3, 2020 (257-268)}

(12) Powers E. M. 1980, Google Patents.

(13) CLSI, (2015).

(14) Assafi M. S., Ibrahim N. M. R., Hussein N. R., Taha A. A., and Balatay A. A., Int. J. Pure Appl. Sci. Technol., 30(2): 54-63 (2015).

(15) Dason S., Dason J. T., and Kapoor A., Can. Urol. Assoc. J., 5(5): 316-22 (2011).

(16) Magliano E., Grazioli V., Deflorio L., Leuci A. I., Mattina R., Romano P., and Cocuzza C. E., ScientificWorld Journal, 2012: 349597 (2012).

(17) Minardi D., d'Anzeo G., Cantoro D., Conti A., and Muzzonigro G., Int. J. Gen. Med., 4: 333-43 (2011).

(18) John A. S., Mboto C. I., and Agbo B., Euro. J. Exp. Bio., 6(4): 7-11 (2016).

(19) Khalifa K., Ali M. F., Abo el Ela O., and el Ayaat A., Chemioterapia, 6(2 Suppl): 500-2 (1987).

(20) Al Yousef S. A., Younis S., Farrag E., Moussa H., Bayoumi F. S., and Ali A. M., Ann. Clin. Lab. Sci., 46(4): 393-400 (2016).

(21) Lin J. C., Koh T. H., Lee N., Fung C. P., Chang F. Y., Tsai Y. K., Ip M., and Siu L. K., Gut. Pathog., 6: 21 (2014).

(22) Varughese L. R. and Beniwal V., Indian Journal of Biotechnology, 14: 167-171 (2015).

(23) Sattar A., Khan A. F., Mustafa K. J., and Khan H., South Asian Journal of Emergency Medicine, 2(2)(2019).

(24) Lee D. S., et al., Int. J. Infect. Dis., 51: 89-96 (2016).

(25) Ahmed I., Sajed M., Sultan A., Murtaza I., Yousaf S., Maqsood B., Vanhara P., and Anees M., EXCLI Journal, 14: 916 (2015).

(26) Nirwati H., et al., BMC Proc., 13(Suppl 11): 20 (2019).

(27) Yang D. and Zhang Z., Journal of Hospital Infection, 68(4): 369-371 (2008).

(28) Mahata A., Swain K. C., and Singha C., International Journal of Basic and Applied Biology, 5(2): 84-90 (2018). 
(29) Meatherall B. L., Gregson D., Ross T., Pitout J. D., and Laupland K. B., Am. J. Med., 122(9): 866-73 (2009).

(30) Hussein N. R., Assafi M. S., and Ijaz T., J. Glob. Antimicrob. Resist., 9: 78-81 (2017).

(31) Polse R. F., Yousif S. Y., and Assafi M. S., Journal of Microbiology and Infectious Diseases, 6(3): 163-167 (2016).

(32) Abdulrahman I. S., Science Journal of University of Zakho, 6(2): 46-50 (2018).

(33) Biradar S. and Roopa C., International Journal of Current Microbiology and Applied Sciences, 4(9): 991-995 (2015).

(34) Esan C. O., Famurewa O., Lin J., and Shittu A. O., Afr. J. Microbiol. Res., 3(12): 962-968 (2009).

(35) Assafi M. S., Hado H. A., and Abdulrahman I. S., Iraqi Journal of Veterinary Sciences, 34(1): 15-22 (2020).

(36) Gajdacs M., Abrok M., Lazar A., and Burian K., Medicina (Kaunas), 55(7)(2019).

(37) Cristea O. M., Avramescu C. S., Balasoiu M., Popescu F. D., Popescu F., and Amzoiu M. O., Curr. Health Sci. J., 43(2): 137-148 (2017).

(38) Moini A. S., Soltani B., Taghavi Ardakani A., Moravveji A., Erami M., Haji Rezaei M., and Namazi M., Jundishapur J. Microbiol., 8(10): e27517 (2015).

(39) Dumaru R., Baral R., and Shrestha L. B., BMC Research Notes, 12(1): 38 (2019).

(40) Huang X.-Z., Frye J. G., Chahine M. A., Glenn L. M., Ake J. A., Su W., Nikolich M. P., and Lesho E. P., PLoS One, 7(7)(2012).

(41) Aljanaby A. A. J. and Alhasnawi H., Pak. J. Biol. Sci., 20(5): 217-232 (2017).

(42) Suh B. and Lorber B., Med. Clin. North. Am., 79(4): 869-94 (1995).

(43) Ball P., J. Antimicrob. Chemother., 46 Suppl T1: 17-24 (2000).

(44) Ferreira R. L., et al., Frontiers in Microbiology, 9: 3198 (2019).

(45) Bush K., Antimicrobial Agents and Chemotherapy, 62(10)(2018). 
(46) Bialek-Davenet S., et al., Emerg. Infect. Dis., 20(11): 1812-20 (2014).

(47) Bernardini A., Cuesta T., Tomas A., Bengoechea J. A., Martinez J. L., and Sanchez M. B., Int. J. Antimicrob Agents, 53(1): 29-33 (2019).

(48) Wyres K. L., Lam M. M. C., and Holt K. E., Nat. Rev. Microbiol., (2020).

(49) Rawat D. and Nair D., Journal of Global Infectious Diseases, 2(3): 263 (2010).

(50) Shon A. S. and Russo T. A., Future Microbiol., 7(6): 669-71 (2012).

(51) Gu D., et al., Lancet Infect. Dis., 18(1): 37-46 (2018).

(52) Chen L. and Kreiswirth B. N., Lancet Infect. Dis., 18(1): 2-3 (2018).

(53) Meletis G., Ther. Adv. Infect. Dis., 3(1): 15-21 (2016). 